\title{
FLORISTIC DIVERSITY AND DYNAMICS OF ISLA RASA, Gulf of CALIFORNiA - A GLOBALly IMPORTANT SEABIRD ISLAND
}

\author{
Enriqueta Velarde ${ }^{1}$, Benjamin T. Wilder ${ }^{2,6}$, Richard S. Felger ${ }^{3,4}$ and Exequiel Ezcurra ${ }^{2,5}$ \\ 'Instituto de Ciencias Marinas y Pesquerías, Universidad Veracruzana, Boca del Río, Veracruz, Mexico \\ ${ }^{2}$ Department of Botany and Plant Sciences, University of California, Riverside, California, USA \\ ${ }^{3}$ University of Arizona Herbarium, Tucson, Arizona, USA \\ ${ }^{4}$ Sky Island Alliance, Tucson, Arizona, USA \\ ${ }^{5}$ University of California, Institute for Mexico and the United States (UC MEXUS), Riverside, California, USA \\ ${ }^{6}$ Corresponding author: benjamin.wilder@email.ucr.edu
}

\begin{abstract}
Isla Rasa, a small $\left(0.68 \mathrm{~km}^{2}\right)$ but globally important seabird island in the Gulf of California, has a flora of only 14 vascular plant species found in three vegetation zones. Significant physical alteration of the island's surface and the introduction of non-native rodents, eradicated in 1995, add restoration ecology to the remarkable biology of the island. Over a century of botanical collections and observations record a consistently depauperate flora, best understood in the context of extreme aridity, isolation, and elevated levels of nitrogen and phosphorus from bird guano. The shaping factor of guano on the dearth of floristic diversity illustrates close connection between marine and terrestrial ecosystems in the Gulf of California. El Niño events that trigger collapses in marine productivity and crashes in seabird reproduction bring above-average winter rainfall pulses and rapid plant growth. Two new island records are reported (Rhizophora mangle and Viscainoa geniculata). Matched photographs show significant increase in the cholla cactus (Cylindropuntia fulgida) since 1971. Baseline knowledge of seabird breeding ecology and the flora of the island position Isla Rasa as a preeminent locality to study and monitor the ecological dynamics of a desert island in the context of restoration ecology and global environmental change.
\end{abstract}

Keywords: biogeography, ecosystem dynamics, El Niño, immigration, islands.

Resumen: Isla Rasa, una isla pequeña $\left(0.68 \mathrm{~km}^{2}\right)$ pero globalmente importante para la anidación de aves marinas en el Golfo de California, posee una flora de sólo 14 especies de plantas vasculares en tres zonas de vegetación. La importante alteración física de la superficie de la isla, y la introducción de dos especies de roedores, agregan la restauración ecológica debido a la erradicación de estos últimos en 1995, a la notable historia biológica de la isla. Más de un siglo de observaciones y colecciones botánicas registran una flora consistentemente depauperada, que se comprende mejor en el contexto de aridez extrema, aislamiento, y niveles elevados de nitrógeno y fósforo en el suelo provenientes del guano de las aves. El guano como factor de la baja diversidad florística ilustra la conexión entre los ecosistemas marinos y terrestres del Golfo de California. Los eventos de El Niño, que causan abatimiento en la productividad marina y colapsos en la reproducción de las aves, traen también eventos extraordinarios de lluvia y consecuentemente crecimiento vegetal. Dos nuevos registros insulares son reportados (Rhizophora mangle y Viscainoa geniculata), y fotografías comparadas revelan un incremento significativo en la cobertura de una especie de choya (Cylindropuntia fulgida) desde 1971. Una detallada línea de base de la ecología de aves marinas y de la flora insular ubican a Isla Rasa como una localidad destacada para el estudio y el monitoreo de la dinámica ecológica de una isla desértica, en el contexto de la restauración ecológica y los estudios de cambio ambiental global.

Palabras clave: biogeografía, dinámica de ecosistemas, El Niño, inmigración, islas.

I nterest in floristic diversity and vegetation dynamics has increased in recent times, mainly due to the progressively erratic nature of climate patterns and associated rates of biological change (Holmgren et al., 2001). In particular, islands have factored into the foundational understanding of the natural world as discrete and often small habitat entities. Such studies have revealed mechanisms for species turnover and the possibility to perceive biological phenomena in isolation. In this respect, Isla Rasa in the Gulf of California has been a remarkable example of conservation, research, and restoration for the last 50 years. Observations in Rasa are particularly important because of the porous ocean-land interface mediated by the abundant seabirds and inter-annual climatic variability. For over 100 years human impacts had 
drastic effects on the island, during which, floristic observations and collections have regularly been made, accumulating over a centuries worth of baseline data for a long-term ecological restoration project. The biological diversity and dynamics of this small island are reliable indicators of both local and global environmental (climatic and oceanographic) conditions and, as a result, valuable indicators of climatic change. Isla Rasa is, in some way, a resounding box where global scale phenomena are manifested and amplified.

Isla Rasa is a small $\left(0.68 \mathrm{~km}^{2}\right)$ desert island located in the rich upwelling region of the Midriff Islands of the Gulf of California, a region of globally high marine productivity (Murphy et al., 2002; Vieyra et al., 2009; Figures 1, 2). The island supports the world's largest breeding populations of Heermann's Gulls (Larus heermanni) and Elegant Terns (Thalasseus elegans; Velarde and Anderson, 1994; Velarde et al., 2005). Due to the massive numbers of these and other seabirds, the island is white-washed in large amounts of guano and the corresponding high levels of nitrogen and phosphorus largely determine the plant species that can persist. In addition, to the harsh soil conditions, Rasa is isolated; formed from a recent volcanic eruption in the middle of the Gulf of California. It is ca. $20 \mathrm{~km}$ from the nearest point of the Baja California Peninsula, $38 \mathrm{~km}$ from the southwest corner of Isla Tiburón near the Sonoran mainland, and 7.2 $\mathrm{km}$ from Partida, or Cardonosa, the nearest island. Isla Rasa is in one of the most arid regions of the Sonoran Desert and has relatively little topographic relief. Precipitation is scant and unpredictable, the largest amounts coming in pulses from winter rains associated with El Niño events and rare warm-season rain events from tropical storms that track up the Gulf of California (García, 1964). During summer months, and at other times of the year during El Niño events, fog may occur due to warm air entering an area of cold ocean

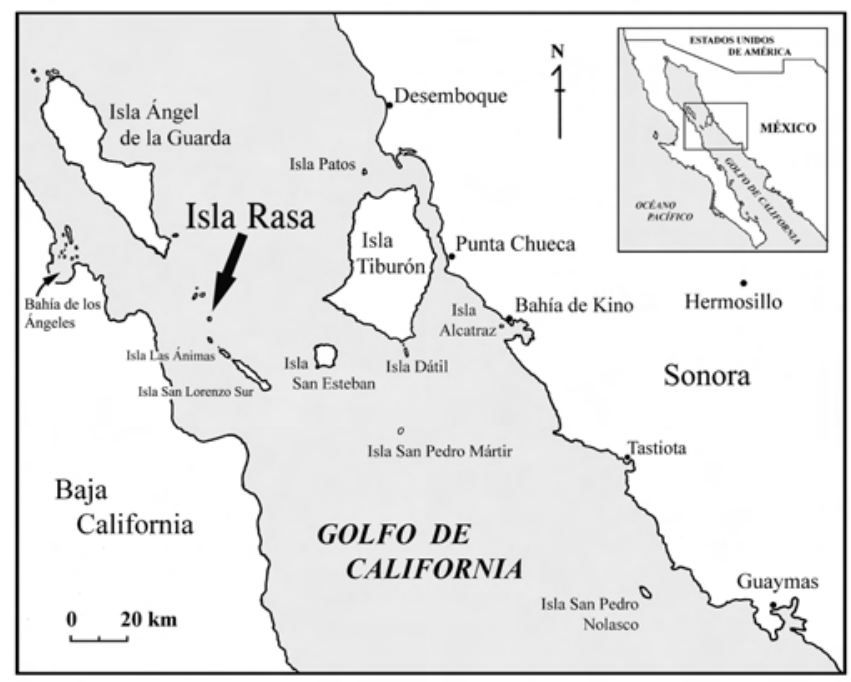

Figure 1. Map of the Midriff Islands, Gulf of California, Mexico (by Cathy Moser Marlett). upwelling. Fog condenses on vegetation surfaces, especially cacti such as cardón (Pachycereus pringlei), pitaya agría (Stenocereus gummosus), and cholla (Cylindropuntia fulgi$d a$ ), and can be a major source of moisture for some plants (Wilder and Felger, 2010). The combination of these factors yields a small, yet dynamic flora of 14 species.

Isla Rasa is one of the youngest islands in the gulf, with an estimated age of only 10,000 years (Carreño and Helenes, 2002). The island is volcanic in origin, consisting mainly of massive and lesser fragments of basaltic rock among which a scant soil has accumulated, with a shoreline of basaltic boulders and a few low cliffs at the southeast end. There are several hills, the highest rising $30 \mathrm{~m}$ above sea level (Figure 3 ). Most of the island, however, is nearly level, hence the Spanish name Rasa, which means flat or smooth (the name "Raza," meaning race, has been consistently misapplied to the island). There are three tidal lagoons, all on the northwest end of the island. The easternmost lagoon was artificially opened to the sea (in order to allow access for small skiffs) and drains completely at low tide. The other two are open to the sea only at highest tides and remain partially full at low tide. Most hills and the valleys between them (the latter originating from guano deposits from birds nesting on the island), as well as the tidal lagoons, are aligned approximately in a north northwest-south southeast direction. Geologic studies indicate that the island is rising and the valleys at lower-elevations must have been lagoons since soil-core studies revealed mollusks in the process of fossilizing in the lower strata of sand, which overlay basaltic rock. Soil profiles elsewhere on the island show only guano over the basaltic rock (Vidal, 1967).

The most significant historic use of the island has been the extensive guano-mining operations in the late nineteenth and early twentieth centuries. Thomas Bowen (2000) provides the best overview of such operations, highlights of which are provided here. The massive number of seabirds that used Rasa as a sanctuary for breeding, due to the absence of mammalian predators, deposited such quantities of guano that international companies exploited the resource. Guano mining began sometime before 1873, but exploitation was at low levels. Industrial extraction of the guano began in 1873 and continued into the 1910s, although at lower yields by the end of this era (Bowen, 2000). The guano mining operations required massive disturbance of the substrate: large numbers of medium size basalt boulders were manually removed by the miners from the hill surfaces and stacked into cairns (an estimated 11,200 structures; Bowen, 2000), and low long walls along many of the hills of the island. The pebbles left behind after the removal of these relatively large boulders created a surface resembling a desert pavement. The original substrate of the valleys, consisting of guano, was harvested using shovels and transported to boats. After guano mining ceased people began harvesting bird eggs in commercial quantities, re- 


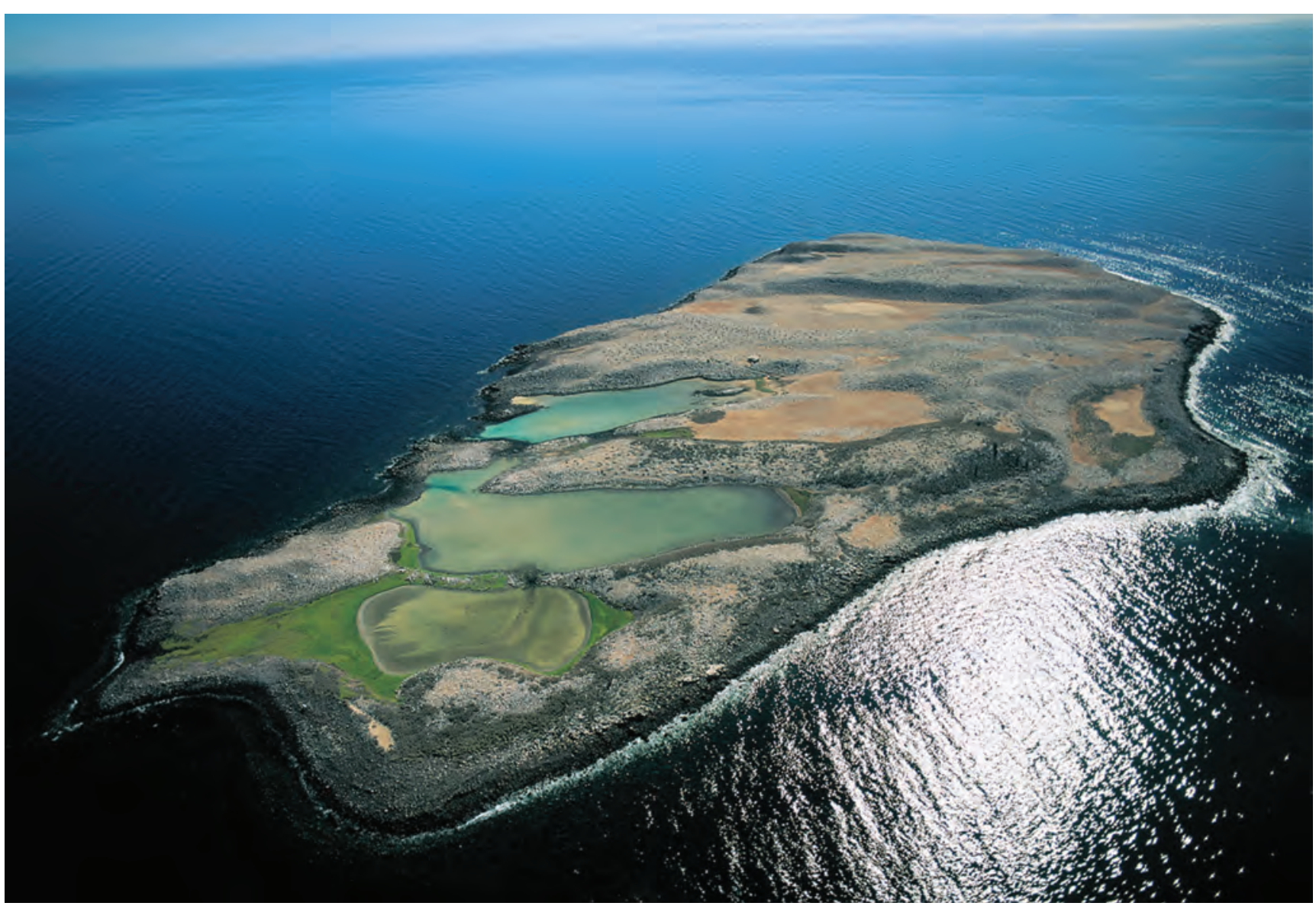

Figure 2. Aerial photograph of Isla Rasa; view looks to the northeast (photo by Fulvio Eccardi).

aching 50,000 eggs per year (Villa, 1976). Egg collection was practiced by local Baja California people who, in order to obtain fresh eggs for market, would travel to the island in small boats during the start of the laying season and destroy all eggs they could find so that the birds would lay fresh eggs (without developed embryos). A few days later they would collect the fresh eggs and take them to their towns for sale. This practice continued until 1964 when Rasa was given federal protection as a wildlife reserve.

In addition to disruption to the breeding habits and habitats of the sea birds during the years of guano mining and egg harvesting, house mice (Mus musculus) and black rats (Rattus rattus) became established. These introductions had significant effects on the sea bird populations and undoubtedly on some, if not all of the plants. The nesting populations (numbers unknown) of Craveri's Murrelet (Synthliboramphus craveri) and Black-vented Shearwater (Puffinus opisthomelas) were extirpated from the island, and the breeding success of Heermann's Gulls (Larus heermanni) and Elegant Terns (Thalasseus elegans) was drastically reduced.

The conservation story of Isla Rasa has multiple chapters and is central to the conservation of the Gulf of California as a whole. A popular article in National Geographic by Lewis
Wayne Walker (1951) highlighted the natural wealth of the islands in the Gulf by documenting the awe-inspiring gathering of hundreds of thousands of seabirds on the small desert island of Rasa. This article and associated popular media gained international recognition for the Gulf of California, which resulted in private donations made for the conservation and research of the seabird ecology on Rasa. This effort was headed by Dr. Bernardo Villa of the Instituto de Biología of the Universidad Nacional Autónoma de México (UNAM) in Mexico City in the 1960s, with whom the lead author first traveled to the island and began her work. Concern grew over crashing seabird populations in the late 1950s and early 1960s, largely due to excessive egg collecting. An international collaboration between Mexican and American scientists, museum administrators, and local citizens petitioned the Mexican government to conserve Isla Rasa. Their work culminated in the island being declared a federally protected area in 1964 by the Mexican Federal Government under the official designation of Zona de Reserva Natural y Refugio de Aves (DOF, 1964). This foundation of conservation success led to continued scientific inquiry by researchers and students in the region, which grew into initiatives to expand understanding and conservation to other 
islands in the Gulf. Additional layers of protection have subsequently been afforded to Rasa and the Gulf as a whole. In 1978, Isla Rasa became part of the much larger protected area under the official designation of Área de Protección de Flora y Fauna Islas del Golfo de California (DOF, 2000), which in 2005 were made a United Nations World Heritage site along with the marine and coastal protected areas of the Gulf of California. Because initially only the land portion of the islands was protected, in 2005 the waters around the group of islands between Partida and San Lorenzo, including Rasa, Salsipuedes and Las Ánimas, were protected under the official designation of Parque Nacional exclusivamente la zona marina que circunda al complejo insular conocido como Archipiélago de San Lorenzo (DOF, 2005), and all the waters within five to seven nautical miles around these islands received protection as well. In February 2006, Isla Rasa was recognized as a wetland of international importance by the Ramsar Convention. In 2007 the waters included in Bahía de los Ángeles, Canal de Ballenas and Canal de Salsipuedes were declared a Biosphere Reserve under the name Reserva de la Biosfera Bahía de los Ángeles, Canales de Ballenas y Salsipuedes (DOF, 2007). From 1979 to the present, E. Velarde and her team have spent every spring monitoring the seabird-breeding season on the island. The base of operations consists of a small house built in 1964 on the NW side of the island, close to the shores of the easternmost intertidal lagoon, by the Secretaría de Agricultura y Ganadería, the Mexican federal environmental agency of the time. This research team has been quantifying the populations and breeding and feeding ecology of the seabird species that nest on the island, and protecting the birds from egg collectors and other disturbances.

One of the most substantial conservation actions was the eradication of the introduced rodents (there are no native land mammals on the island). In 1993-1994 the monitoring of the populations of these rodents was carried out in preparation for their eradication. The late Jesús Ramírez carried out the first island eradication program in Mexico, eradicating introduced rats and mice on Isla Rasa in 1995 (Ezcurra et al., 2002). The work was done using modern rodenticides, which were placed over the entire island. Complete eradication was achieved in two months and immediate increases were seen in seabird breeding populations. This eradication effort served as a model for other similar initiatives, such as the elimination of the black rat on Isla San Pedro Mártir, which was completed in 2007 (Samaniego-Herrera et al., 2008).

Due to the shaping forces the island fauna has on the plant life, we here provide a brief overview of the animals found on Isla Rasa. There is a plethora of literature of the subject, with especially important references in the different chapters of Case and Cody (1983) and Case et al. (2002).

Birds. Several studies focused on seabird breeding biology and physiology, including adaptations to the desert environ- ment, which were done after the establishment of the protected area (see Velarde-González, 1989 for overview). Over 80 species have been documented for the island (Velarde González, 1989; Cody and Velarde, 2002; Velarde personal observation). However, the most important ornithological aspect is that about 95 percent of the world population of two seabird species nest on the island in spring, from April through June: Heermann's Gull (Larus heermanni), with some 260,000 individuals, and Elegant Tern (Thalasseus elegans) with a 2008 nesting population of some 200,000 individuals, as well as the most important nesting population of Royal Terns (Thalasseus maximus) of North America with up to 17,000 individuals.

Bird surveys conducted before the guano extraction operations report Craveri's Murrelet (Synthliboramphus craveri) nesting on the island (Bent, 1919); while Black-vented Shearwater (Puffinus opisthomelas) burrows could be seen in the early 1900s, after the cessation of guano mining (Bancroft, 1927). These two species had not been reported nesting on the island until recent evidence found by Velarde indicated these species are nesting there again (Velarde et al., 2011).

Reptiles. The side-blotched lizard (Uta stansburiana) and a gecko (Phyllodactylus tinklei) have been reported from the island (Murphy and Aguirre-León, 2002). One spiny chuckwalla, Sauromalus hispidus, was discovered in 2006 at the south end of the island (Velarde et al., 2008). Several scats of the chuckwalla consisted of ca. 90 percent leaf material of the small coastal plant Cressa truxillensis that is abundant in the valley called Tapete Verde.

Mammals. No native land mammals or pinnipeds have been reported on the island. The nearby rock outcrops Roca Rasa and Roca Partida, however, have breeding colonies of California sea lions (Zalophus californianus). Bats are not known to occur on Rasa, although Isla Cardonosa (Partida Norte), only $7 \mathrm{~km}$ northwest from Rasa, has a significant population of fishing bats, Myotis [Pizonyx] vivesi (Maya, 1968).

It is the goal of this paper to highlight, through analysis of the floristic diversity and ecology of Isla Rasa, the unique stories of restoration conservation, ecological dynamics, and migration and extinction made possible with long-term data sets.

\section{Materials and Methods}

A floristic list for Isla Rasa was compiled from collections beginning with those of Edward Palmer in 1890 (Vasey and Rose, 1890) to the present, and previous species lists for the island (Johnston, 1924; Gentry, 1949; Moran, 1983; Moran and Rebman, 2002). A rich history of botanical collections for over a century and at nearly 30 -year intervals provides a comprehensive long-term record of the island flora. We 
searched for specimens from the island at the herbaria of the University of Arizona (ARIZ), San Diego Natural History Museum (SD), and other regional collections, including the California Academy of Sciences (CAS), the University of California, Berkeley (UC), and the Herbario Nacional, Universidad Nacional Autónoma de México, Mexico City (MEXU). We also made use of pertinent information regarding Isla Rasa specimens from databases at SD, the online Southwest Environmental Information Network (SEINet), and elsewhere, and information for select species of interest housed at other herbaria. Additional insights were gained by consulting the original field notes of botanists who visited the island, especially those of James Rodney Hastings (courtesy of Raymond Turner), Reid Moran (housed at SD; Moran 1936-1993), and Ira L. Wiggins (housed at the CAS). The two new species records were discovered by E. Velarde, in addition to her records of the island flora through photos and field notes. Insight into the dynamics of the islands flora were aided by Velarde's observations made during her annual field seasons on the island, since 1979 during the seabird breeding period and the use of matched photos taken in March 1971 by Rodney Hastings and re-photographed in April 2012 by Thor Morales. Velarde's collections were made under a Mexican federal collecting permit and specimens are deposited at SD.

\section{Results}

The vascular flora is composed of 14 species in 13 genera and nine families. The Cactaceae are the most diverse fami- ly with five species in four genera. There are eight succulent species (three halophytic succulents and five xerophytic succulents, one of which is a columnar arborescent form, Pachycereus pringlei; Wilder et al., 2008), three herbaceous perennials, and three shrubs (Table 1).

The 14 species are known to occur near the shore on nearby larger land masses. There are three main biogeographic distributional patterns: (1) Gulf of California region, eight species; (2) Mega-Mexico pattern 1 (Rzedowski, 1991), Arthrocnemum subterminalis and Distichlis littoralis; and (3) New World and Cosmopolitan, four species (Table 1).

Vegetation. The three major habitats on the island support three plant communities (Felger and Lowe, 1976; Felger and Wilder, 2012). These are (Figure 3):

(I) Tidal lagoons (esteros), which support salt scrub species. The three lagoons on the island support a salt scrub community adapted to saline conditions and is composed of a salt grass (Distichlis littoralis), the three halophytic succulents (Arthrocnemum subterminalis, Batis maritima, and Sesuvium portulacastrum), and the recent arrival of a mangrove (Rhizophora mangle).

(II) Guano flats support guano-tolerant species. In the Midriff Region many of the smaller "bird islands" (e.g., Alcatraz, Patos, San Pedro Mártir, and certain islands in Bahía de Los Ángeles) support species that are able to tolerate and in some cases thrive in soil conditions that are toxic for most plants (cactus diversity is relatively greater on these smaller islands than on larger islands, see Wilder et al., 2008). On Rasa the classic guano-adapted species common on "bird

Table 1. Flora of Isla Rasa, growth form, biogeographic region of distribution, and historic collections. Note, lack of collection of all species besides Rhizophora and Viscainoa by earlier botanists does not necessarily mean species was not present, especially cacti which are commonly not pressed. ${ }^{a}$ Growth forms: $\mathrm{HP}=$ herbaceous perennial, $\mathrm{HS}=$ halophytic succulent, $\mathrm{S}=$ shrub, XS = xerophytic succulent. ${ }^{\mathrm{b}} \mathrm{Generalized}$ biogeographical groups: (1) Gulf of California; (2) Mega-Mexico 1; (3) New World and cosmopolitan.

\begin{tabular}{|c|c|c|c|c|c|c|c|}
\hline Species & $\begin{array}{l}\text { Growth } \\
\text { form }^{\mathrm{a}}\end{array}$ & $\begin{array}{l}\text { Biogeographic } \\
\text { region }^{b}\end{array}$ & $\begin{array}{c}\text { Palmer } \\
1890\end{array}$ & $\begin{array}{c}\text { Johnston } \\
1924\end{array}$ & $\begin{array}{c}\text { Moran } \\
1962\end{array}$ & $\begin{array}{c}\text { Hastings } \\
1971\end{array}$ & $\begin{array}{c}\text { Velarde } \\
2008\end{array}$ \\
\hline Sesuvium portulacastrum & $\mathrm{HS}$ & 3 & $P$ & $J$ & M & & $\mathrm{V}^{*}$ \\
\hline Arthrocnemum subterminalis & $\mathrm{HS}$ & 2 & $\mathrm{P}$ & & M & & $\mathrm{V}^{*}$ \\
\hline Atriplex barclayana & $\mathrm{HP}$ & 1 & $\mathrm{P}$ & J & M & $\mathrm{H}^{*}$ & $\mathrm{~V}^{*}$ \\
\hline Batis maritima & $\mathrm{HS}$ & 3 & & $J$ & M & $\mathrm{H}^{*}$ & $\mathrm{~V}^{*}$ \\
\hline Cylindropuntia alcahes & XS & 1 & $\mathrm{P}$ & & M & $\mathrm{H}^{*}$ & $\mathrm{~V}^{*}$ \\
\hline Cylindropuntia fulgida & XS & 1 & $\mathrm{P}$ & & M & $\mathrm{H}^{*}$ & $\mathrm{~V}^{*}$ \\
\hline Lophocereus schottii & $\mathrm{XS}$ & 1 & & & $M^{*}$ & $\mathrm{H}^{*}$ & $\mathrm{~V}^{*}$ \\
\hline Pachycereus pringlei & $\mathrm{XS}$ & 1 & & & $M^{*}$ & & $\mathrm{~V}^{*}$ \\
\hline Stenocereus gummosus & $\mathrm{XS}$ & 1 & & & $M^{*}$ & $\mathrm{H}^{*}$ & $\mathrm{~V}^{*}$ \\
\hline Cressa truxillensis & $\mathrm{HP}$ & 3 & & J & M & $\mathrm{H}$ & $\mathrm{V}^{*}$ \\
\hline Distichlis littoralis & $\mathrm{HP}$ & 2 & & J & M & & $\mathrm{V}^{*}$ \\
\hline Rhizophora mangle & S & 3 & & & & & V \\
\hline Lycium brevipes & $S$ & 1 & & $J$ & M & $\mathrm{H}^{*}$ & $\mathrm{~V}^{*}$ \\
\hline Viscainoa geniculata & $\mathrm{S}$ & 1 & & & & & $\mathrm{~V}$ \\
\hline
\end{tabular}

*Species was not collected but observed as evidenced by the collector's field notes and/or photos. 


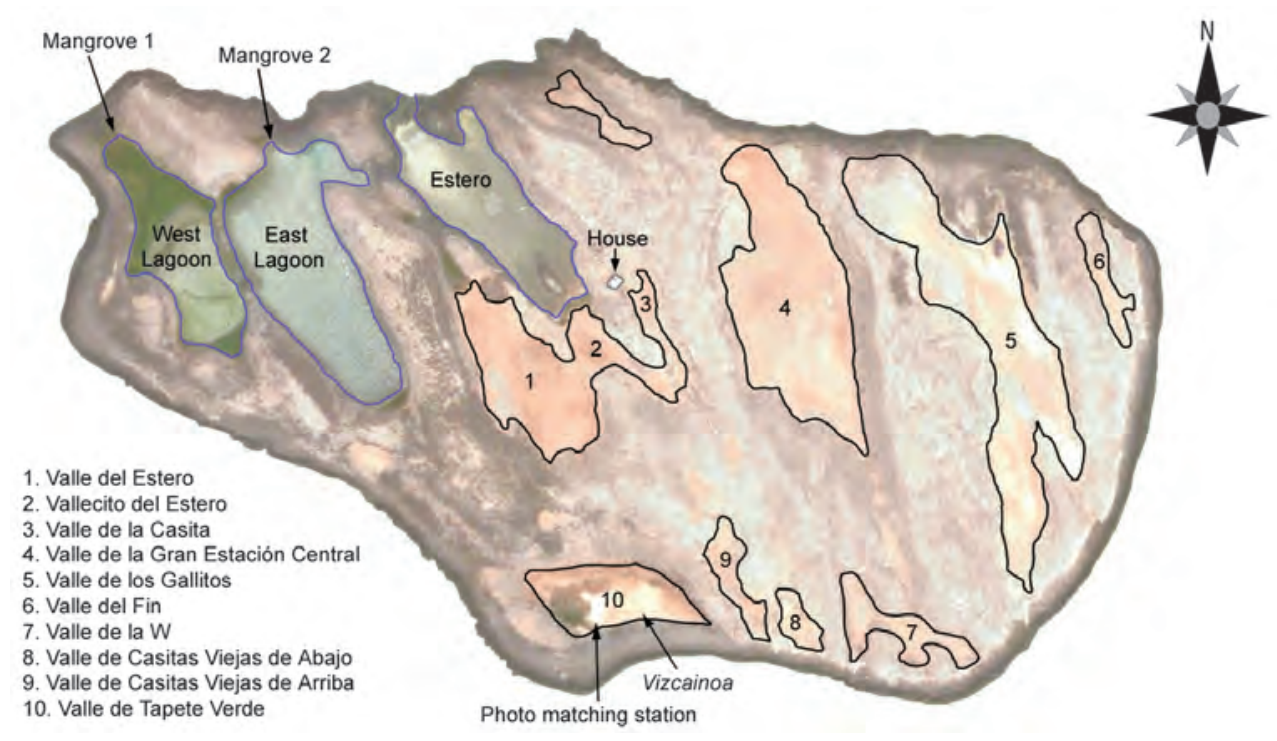

Figure 3. Isla Rasa, showing place names, locations of the new plant species, and most relevant features. The three vegetation zones follow the three habitats of the island: guano-tolerant species on the guano flats or the valleys, outlined in black; salt scrub in the three tidal lagoons (esteros), outlined in blue; desertscrub on the rocky areas of flats and hills, the remainder of the island.

islands" in the Gulf are Atriplex barclayana, Lycium brevipes, and the recently recorded Viscainoa geniculata. Cressa truxillensis is the principal guano-flat species in one of the valleys, which gives the Tapete Verde locality its name. Brackish water was found at the bottom of this valley when soil cores were taken, which may be an explanation for the density of Cressa (Felger et al., 2012).

(III) Rocky areas of flats and hills support a highly limited desertscrub community. The subtle relief of this area supports all cactus species on the island and the saltbush, Atriplex barclayana. Cylindropuntia fulgida var. fulgida is the dominant plant and forms impenetrable colonies, and probably is one of the densest populations of any species of Cylindropuntia in the entire Gulf of California region. Cylindropuntia alcahes occurs in a dense stand on the hill facing the easternmost lagoon. This latter cholla species and the other cactus species generally occur on Rasa as scattered single or relatively few individuals.

Flora. Previous checklists for the island flora (Johnston, 1924; Gentry, 1949; Moran, 1983; Moran and Rebman, 2002), collectively list 16 species for the island (including four species we treat as doubtful and excluded). We report 14 species, including two new records, Rhizophora and Viscainoa. An important aspect of our knowledge of the island's flora is the legacy of historical botanical collections (Table 1). This solid baseline permits us to conclusively state these two new records are indeed recent immigrants, in light of their not having been documented over the last century. The following species list adheres to the following format: accepted scientific family name following APG III nomenclature (Angiosperm Phylogeny Group), selected synonyms (in brackets), vernacular names when known, first in Spanish (italics) then English, and the family in parentheses, and finally followed by the citation of a representative herbarium voucher anchoring the species to the island. We have seen all specimens cited. Species are listed in alphabetical order first by family and then by genus and species.

1. Sesuvium portulacastrum L. Sea purslane (Aizoaceae). 26 Mar 1962, Moran 8923 (SD).

2. Arthrocnemum subterminalis (Parish) Standley [Salicornia subterminalis Parish]. Pickleweed, glasswort (Amaranthaceae). 28 Apr 1966, Moran 13066 (SD).

3. Atriplex barclayana (Bentham) Dietrich. Chamizo, saladillo, oreja de burro; costal saltbush (Amaranthaceae). 12 Feb 1890, Palmer 158 (CAS).

4. Batis maritima Linnaeus. Dedito; saltwort (Bataceae). 21 Apr 1921, Johnston 3217 (CAS).

5. Cylindropuntia alcahes (F.A.C.Weber) F.M.Knuth var. alcahes [Opuntia alcahes F.A.C.Weber var. alcahes]. Choya; Baja California cholla (Cactaceae). 26 Mar 1962, Moran 8927 (SD).

6. Cylindropuntia fulgida (Engelmann) F.M.Kunth var. fulgida [Opuntia fulgida Engelmann var. fulgida]. Choya; chainfruit cholla (Cactaceae). 26 Mar 1962, Moran 8926 (SD).

7. Lophocereus schottii (Engelmann) Britton \& Rose var. schottii. Sinita, músaro; senita, old man cactus (Cactaceae). 12 May 2009, Velarde (photo \#0915).

8. Pachycereus pringlei (S.Watson) Britton \& Rose. Cardón, sagüeso (Cactaceae). 26 Mar 1962, Moran observation (Moran, 1936-1993).

9. Stenocereus gummosus (Engelmann) Gibson \& Horak. Pitaya agria (Cactaceae). 26 Mar 1962, Moran observation (Moran, 1936-1993). 
10. Cressa truxillensis Kunth. Alkali weed (Convolvulaceae). 21 Apr 1921, Johnston 3209 (CAS).

11. Distichlis littoralis (Engelmann) H.Bell \& Columbus [Monanthochlöe littoralis Engelmann]. Zacate playero; shore grass (Poaceae). 26 Mar 1962, Moran 8925 (CAS).

12. Rhizophora mangle Linnaeus. Mangle rojo; red mangrove (Rhizophoraceae). 20 Apr 2008, Velarde (SD).

13. Lycium brevipes Bentham var. brevipes. Salicieso, frutillo; desert wolfberry (Solanaceae). 26 Mar 1962, Moran 8919 (SD).

14. Viscainoa geniculata (Kellogg) Greene var. geniculata. Guayacán (Zygophyllaceae). 20 Apr 2008, Velarde (SD).

Doubtful and excluded species (some authors have reported certain species on Rasa that we have not observed and do not accept as occurring on the island):

Atriplex polycarpa (Torrey) S.Watson. Chamizo cenizo; desert saltbush (Amaranthaceae).

Cylindropuntia cholla (F.A.C.Weber) Knuth [Opuntia cholla F.A.C. Weber]. Choya (Cactaceae).

Stenocereus thurberi (Engelmann) Buxbaum [Lemaireocereus thurberi (Engelmann) Britton \& Rose]. Pitaya dulce; organ pipe cactus (Cactaceae).

Fouquieria diguetii (Van Tieghem) I.M.Johnston [F. peninsularis Nash]. Palo adán (Fouquieriaceae).

Notes and observations. In 1962, coastal saltbush (Atriplex barclayana) was noted to be the most common plant on the island (Moran 1936-1993). However, in dry periods it may be scarce, or not readily visible, as its abundance and distribution fluctuates dramatically, mostly as a result of oceanographic and climatic conditions, and may appear dominant in years of higher rainfall, such as El Niño years. It has a very plastic growth form, being facultatively perennial or annual, seemingly capable of reproducing in a single season.

Chain-fruit cholla (Cylindropuntia fulgida), a clonal species, has been increasing rapidly over the last decades and is now abundant on the island, forming colonies from fallen cladodes and fruits that readily form roots. Several of the rocky hills are partially to almost totally covered by it. Johnston (1924:1117) reported, "A Cylindropuntia apparently related to $O$. cholla is common on Raza and Pond islands. It is characterized by the habit of bearing enormous amounts of pendent many-jointed fruit." C. fulgida and C. cholla are closely related and readily confused by the casual observer.

Cylindropuntia alcahes and especially C. fulgida, both have a negative impact on the nesting birds because many of the chicks and some of the adults that have territories contiguous to the chollas sometimes become impaled and trapped by the spines and generally die (Figure 4). When tern chicks wander close to cholla stands in their walks to the island edge, some of them have the same fate. The increase in cholla coverage may have a significant impact on the seabirds with quite negative results.

Continued observation of the cholla expansion is being undertaken to determine the necessary, if any, management actions needed to buffer the two main seabird species nesting in Isla Rasa that are losing nesting space to the increase of cholla. In this situation it is important to recognize that the two main nesting seabirds on Rasa are included in the Mexican norm for species in risk NOM-059-SEMARNAT (2010), under the category "Special protection" (Pr), and Isla Rasa is the nesting site of approximately $95 \%$ of the world population of these species considered "quasiendemic" to the Gulf of California. Management decisions need to take into account all factors and address the conservation goals at hand.

There are about 20 large individuals of the giant cardón cactus (Pachycereus pringlei) on the island. Velarde noted that in 2004, nine years after the rats and mice were eradicated from the island, two small cardones appeared next to the house. The approximate recorded heights of these two plants were: 2004, $2 \mathrm{~cm} ; 2005,4 \mathrm{~cm} ; 2006,10 \mathrm{~cm} ; 2008$, $80 \mathrm{~cm} ; 2009,110 \mathrm{~cm} ; 2010,150 \mathrm{~cm} ; 2013,180 \mathrm{~cm}$. These plants receive additional water from the nearby outdoor shower used by the researches. Additional plants, ca. $1 \mathrm{~cm}$ tall, were found in the same place in 2008, and were 2 to 4 $\mathrm{cm}$ tall in 2009. Presumably, the cardones have been producing seeds over the years, but the additional water and probably the eradication of rodents has favored the survival of new plants. The growth rate of these individuals is similar to that found for ca. 200 cardones in a long term plot on Isla San Pedro Mártir between 2007 and 2012 (Wilder and Felger, 2010; Wilder unpublished data), which is far faster than previously recognized for this species.

One mangrove plant (Rhizophora mangle), first seen on the island in 2008 when it was ca. $0.5 \mathrm{~m}$ tall, occurs at the west end of the island, in the westernmost lagoon growing among saltwort (Batis). Photos in 2008 show a plant perhaps 3 or 4 years old, with stilt roots. Another individual was recorded in April 2013, with a height of about $50 \mathrm{~cm}$. This individual was not seen in 2012 and may have established as a result of the heavier rainfalls recorded in the summer of 2012. The nearest red mangroves are at Bahía de los Ángeles (ca. $36 \mathrm{~km}$ to the northwest), which is the northernmost occurrence of this species in the Baja California peninsula, the next closest locality is on the northeast side of Isla Tiburón (ca. $80 \mathrm{~km}$ to the east; see Figure 1). It is most likely that the Isla Rasa colonizer originated from Bahía Las Ánimas or further south on the Peninsula due to the predominant north to south currents in the region during the winter months (Beier and Ripa, 1999) and a lack of cross Gulf (east to west or west to east) current flow. This species requires daily tidal flooding and draining for its persistence, which does not occur where the two mangrove plants are found. 


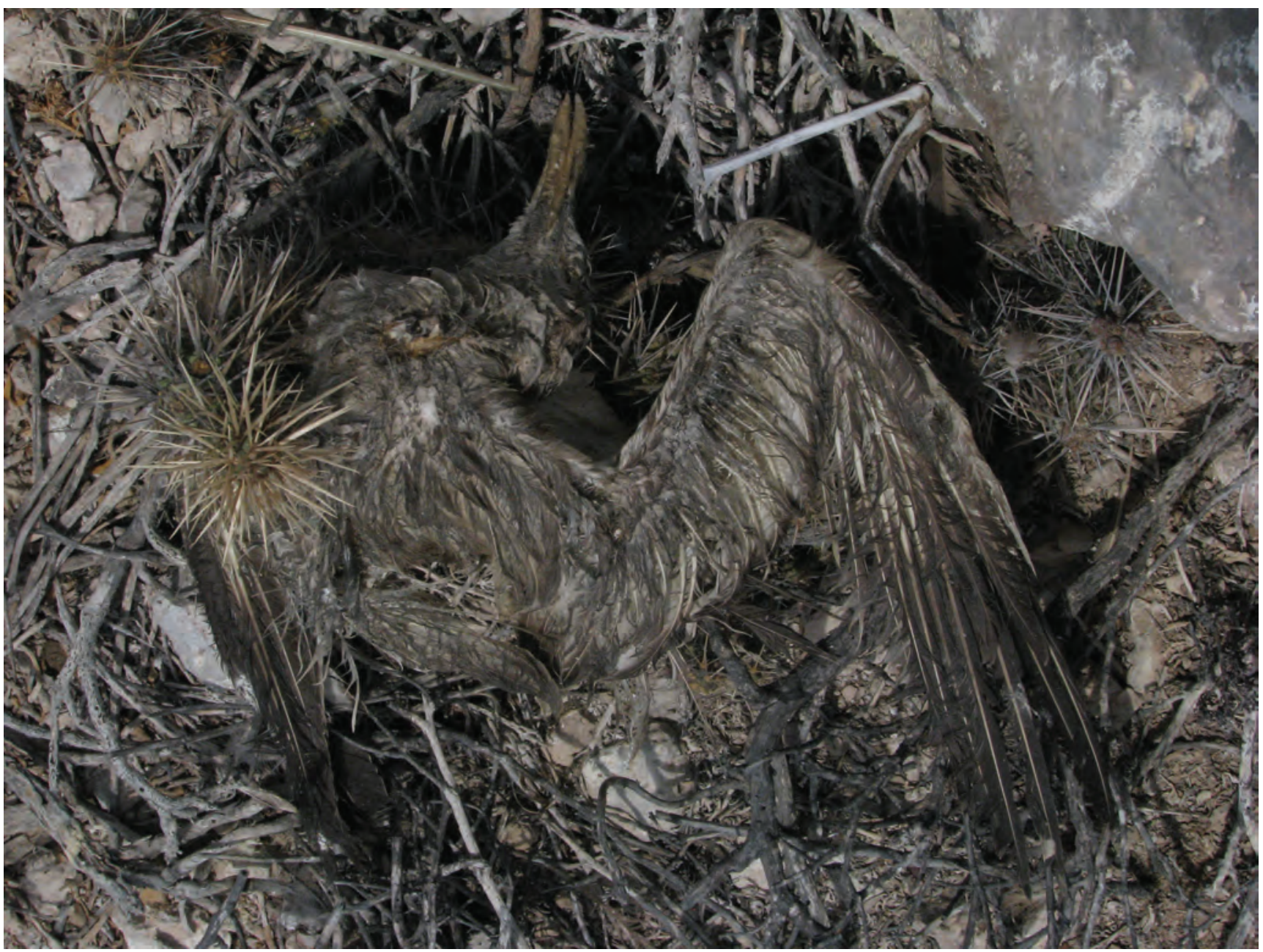

Figure 4. Elegant Tern impaled by a cholla (Cylindropuntia fulgida; photo by Enriqueta Velarde, 19 May 2009).

A single guayacán (Viscainoa geniculata) was first seen on the island in 2006 as a one-meter-tall plant, already with flowers and fruits, and by 2013 had survived with no evident increase in size. It is at the southwest end of the island, close to the shore in the first area inland with soil after the shore boulders. This is the same place where a chuckwalla was found, next to an adult cardón, adjacent to the small valleyarea covered with Cressa.

Repeat photography. The comparison of Rodney Hastings's 1971 images on Isla Rasa and Velarde's matches of 2012 show some stark changes in the vegetation (Figures 5 and 6). The hill depicted in Figure 5 in the 1971 image, taken from the southwest edge of Tapete Verde, looking towards the northwest, shows two small patches of chain-fruit cholla on the left and right of the hill and a scattering of individuals on the middle right, whereas the 2012 image shows the hill almost completely blanketed in a dense cholla thicket (Cylindropuntia fulgida). The five young cardones (Pachycereus pringlei) on the left of the hill, the one on the right, and the clump of the pitaya agria (Stenocereus gummosus) just right of center near the top of the hill in the 1971 image have all persisted and increased in stature by 2012. The halophytic saltscrub community in the foreground has remained stable. The second view (Figure 6) is taken in the same valley, and from the same location, but looking towards the northeast. The cardón from 1971, which at that time had only a single cholla in its proximity, is noticeably thinner with much greater constrictions between growth segments in 2008. In 2012 the cardón is surrounded by a dense stand of chollas (C. fulgida). No appreciable change is detected in the vegetation of the valley, or the slope seen in the background.

\section{Discussion}

The unique geologic and anthropogenic legacy of the Isla Rasa helps shape the floristic diversity seen today, a depauperate assemblage of plant species. At the same time the interaction of one of the richest marine environments in the world and a harshly arid climate combine to form a flora both 


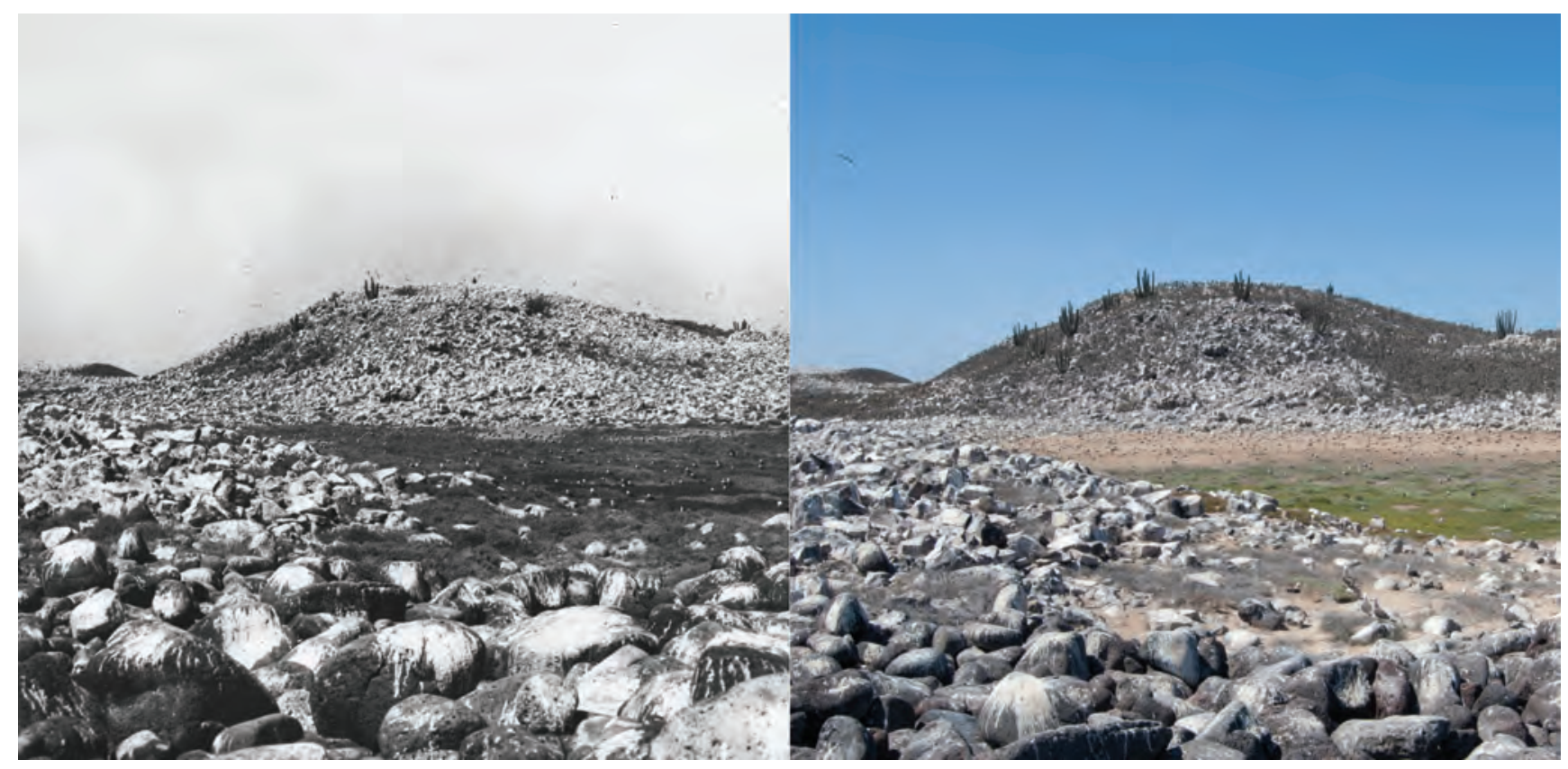

Figure 5. (left) Rodney Hastings photo m33-19, 15 March 1971; and (right) match by Thor Morales, 15 April 2012.

limited and fed by nutrients derived from the sea. This marine and terrestrial interconnection is mediated by oceanic driven climatic pulses such as El Niño events. Many other oceanic islands surrounded by rich marine upwellings face conditions and limiting factors similar to that on Isla Rasa, e.g., the Galapagos in Ecuador and Socotra in Yemen, two of the most important desert insular biodiversity hotspots in the world.

Conservation and restoration. Beyond environmental stochasticity, changing conditions among the plants on Rasa may be attributed to the eradication of the non-native rodents in 1995. There has been increased survival of seedling and small cardones, the cholla expansion may in part be due to release from predation of newly established clones, and the two new species (Rhizophora and Viscainoa) arrived post-eradication. The response of the seabird breeding populations has been remarkable since the rodent eradication. The Elegant Terns, in particular, increased from 30,000 individuals in pre-eradication years to 200,000 in 1999, and have remained high ever since (Velarde and Ez-

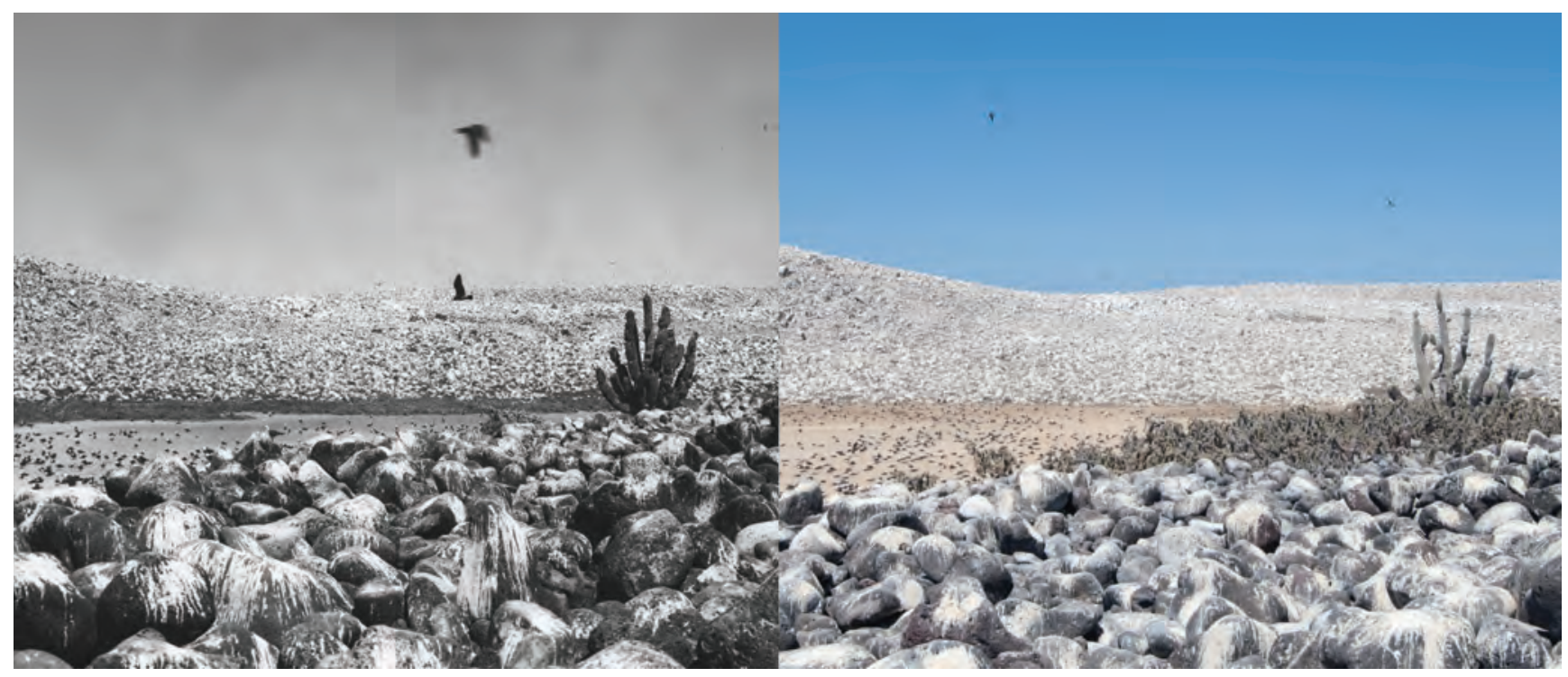

Figure 6. (left) Rodney Hastings photo m33-20, 15 March 1971; and (right) match by Thor Morales, 15 April 2012. 
curra, 2002). On other similar Gulf islands the rodents were known to eat vegetative material (Tershy et al., 1992), and were quite active even in the intertidal areas of Rasa, particularly during the nine months of the year when seabirds were not nesting and there were no eggs, small chicks, and carcasses to consume.

Documenting the changes in flora and fauna on islands that have had non-native rodents removed is critical in gauging the ecological effects of such management actions. The black rat eradication on Rasa was the first such action in Mexico, and thus serves as the preeminent model for anticipating the effects of non-native species removal from other insular ecosystems, as removal of invasive species is an ever-increasing reality in landscape management.

Ecological dynamics. There is direct evidence that the biological diversity of Rasa, at least the island's flora, species composition, and the population dynamics of the nesting sea birds, is not in a static condition, but changes over relatively short periods of time (Anderson et al. 2007, Bowen, 2013). Isla Rasa's location in the western Midriff Region of the Gulf of California, with one of the highest marine productivities in the world (Douglas et al., 2007), is critical for the dense colonies of seabirds that seasonally nest on the island. It is these cold and productive waters that support the great diversity of marine life in the Gulf of California, of which the pelagic fish form the basis of the seabird diet.

The most significant fluctuations seen on Rasa are during El Niño years. El Niño waters enter the Gulf of California from the eastern Pacific and are propagated within the Gulf via coastal trapped waves. This influx of warm water leads to positive anomalies (high temperatures) that are greatest in the Midriff Island Region thermal fronts (Lavín and Marinone, 2003). This warm water decreases coastal upwellings and results in the collapse of much of the primary productivity of the sea and forces long-lived seabirds to skip breeding during these years of low food (Velarde and Ezcurra, 2002; Velarde et al., 2004, Vieyra et al. 2009).

While marine productivity and the subsequent trophic levels suffer acute collapses during El Niño years, winter precipitation tends to increase during these oceanographic anomalies, and terrestrial and insular habitats respond accordingly via a profusion of plant growth (Polis et al., 1997; Holmgren et al., 2001; Caso et al., 2007). The prolific annual plant biomass in response to extreme rain events (El Niño-derived winter storms or warm season tropical storms) is especially prominent on guano rich bird islands due to the added nitrogen and phosphorus in the soil (Polis et al., 1997; Stapp et al., 1999). For example, in El Niño years the facultative annual/herbaceous perennial Atriplex barclayana dominates the flats and rocky hills of Rasa (as well as Isla Patos, a bird island to the north of Isla Tiburón), while it is relatively scarce in drought times. Similarly, on Isla San Pedro Mártir, the annual cucurbit vine Vaseyanthus insularis blankets the island in response to infrequent tropical as well as El Niño storms that strike the island (Wilder and Felger, 2010). It is in these periods of heavy precipitation that the flush of vegetation switches these small island ecosystems from dependence on allochthonous (external) input from the ocean to one driven by in situ terrestrial productivity that draws upon the influx of precipitation and the added nutrients in the guano rich soil (Polis et al., 1997; Stapp et al., 1999).

In addition, to the direct connections formed by seabirds and other organisms between the waters of the Gulf of California and the island ecosystems, certain species play a significant role in decreasing the insularity of the islands. Vagrant avian species, visitors, or unsuccessful colonizers, have been shown to appear on Midriff islands (Rose and Polis, 2000; Gallo-Reynoso et al., 2012). The visitation of these species, primarily terrestrial and marine avian species, is significantly linked to wet years associated with El Niño events (Rose and Polis, 2000). These species can easily be viewed as potential dispersal agents for various plant species. In fact, the majority of the flora of Rasa is adapted to dispersal by birds. In these El Niño years seabird nesting and their associated impact via tromping on the vegetation is diminished, but vagrant visitation increases. Thus, the establishment of immigrant plant species is likely higher.

The increase in the chain-fruit cholla since 1971 is striking. It is not certain at what point within these four decades the increase began, and if the rodent eradication was responsible for, or accelerated this population expansion. It is interesting to note that this same species of cholla throughout its range has been observed to experience dramatic population dynamics. A once mighty and expansive population of Cylindropuntia fulgida var. fulgida in the deserts of the Pinacate Biosphere Reserve in northwestern Mexico in the early 1980s, consisted of thousands of plants, most ca. 2 $\mathrm{m}$ tall (Felger, 2000; Paul Dayton, unpublished photograph; Felger and Ezcurra, personal observations). In 2013, all that remains of this once dense grove are few individuals and decomposing skeletons. This species, like many cholla, forms clonal colonies from fallen cladodes and fruits that readily form roots. This species is triploid and the seeds are likely not viable (Rebman, 1995). Chain-fruit cholla is estimated to have a life span on the order of 40 to 80 years (Turner et al., 2003), and thus may have population fluctuations on a decadal time scale. The reliance on asexual reproduction results in stands of relatively even age, in which the oldest individuals in an aging stand that die off are not replaced. A population may eventually eliminate itself from a given locality (Turner et al., 1995). Turner et al. (2003) via analysis of repeat photo stations throughout the southwest U.S. and northwest Mexico saw a net increase in C. fulgida of $23 \%$ at seventeen photo stations between 1928 and 1963, and a net increase of 35\% at seventeen photo stations between 1963 and 1995. These patterns of expansion and contraction are clearly in line with our observations, and point to the chain- 
fruit cholla being a fascinating indicator of long-term ecological dynamics.

Immigration. In addition to the red mangrove on Rasa, a black mangrove (Avicennia germinans) was found in 2007 in halophytic wetland habitat on Isla Alcatraz off the coast of Bahía Kino, Sonora (Felger and Wilder, 2012). Likewise, on the Pacific Coast of southern Baja California Sur black mangrove cover has substantially increased in the backwaters of lagoons in recent years (López-Medellín et al., 2011). This increase is explained by a combination of high tidal surges seen during El Niño years that deposits the mangrove seedlings inland from the established forest, and a rise of sea level that maintains moist soil conditions allowing continued growth of the new seedlings (López-Medellín et al., 2011). Black mangrove occupies the landward zone with the shallowest water in coastal lagoons, while red mangrove (Rhizophora) consistently occupies the seaward zone with the deepest water throughout the Gulf of California (Felger et al., 2001). The black mangrove of Isla Alcatraz was found ca. $70 \mathrm{~m}$ inland from the regular tide line in the upper fringes of the wetland, while the red mangrove on Rasa was found just above the regular tide line. It is possible that the recent mangroves on Islas Alcatraz and Rasa can be attributed to the tidal and sea level rise forces also at play in southern Baja California Sur, which can be further established via isotopic dating of the new Midriff Island individuals. However, it is also important to keep in mind that there are hundreds of thousands of the water dispersed viviparous mangrove seedlings throughout the Gulf, and their recent occurrence on Rasa will likely not lead to establishment due to the lack of daily tidal inundation.

Viscainoa geniculata is a Baja California-Gulf of California regional endemic and is found on a majority of the Midriff Islands. The seed is covered in an oily orange aril that would make it attractive to birds, which are the likely dispersers (Turner et al., 1995). The fruit of V. geniculata is a multi-valved schizocarp that upon dehiscence splits into separate mericarps or sections that are still attached to the main fruit. The individual mericarps upon drying invert and become positioned beneath the seed, exposing and presenting the oil covered arillate seed to interested consumers. It is easy to envision fruit and seed consuming birds investigating these fruits and if not eating them, having the sticky seeds adhering to their feet or plumage. Although, mostly non-resident, several species of Passeriformes birds have been observed on Isla Rasa on occasional basis, and they may have an important role in the dispersal of these plant species (Cody and Velarde, 2002).

In addition to the recent arrival of this species on Rasa, there is substantial evidence that Viscainoa geniculata is a colonizer of Isla San Pedro Martir where it has substantially increased in population size since its arrival sometime in the middle twentieth century (Wilder and Felger, 2010). This make species' recent colonization of two bird islands in the Gulf of California indicates the important role of birds as dispersal agents in this system as well as an expanding range for this species.

\section{Conclusions}

The baseline biodiversity and long-term ecological data now established for Isla Rasa allow insights into the dynamic nature of life on this desert island. The marine and terrestrial environments have asynchronous productivity responses to global-scale inter-annual climatic variations, which set the stage for a system in constant flux. This connection between oceanic processes, a diverse trophic web, massive colonies of seabirds, and an impoverished flora limited by aridity and high levels of guano, allow for the careful study of Isla Rasa to perceive global phenomena. The eradication of rodents in 1995, the first in all of Mexico, and a changing climate further the unpredictable trajectory of this isolated ecosystem. Continued precise monitoring of the island flora is essential to understand the effects of rodent eradication and the associated ecosystem response. By harnessing over a century of biological knowledge for Rasa, we may begin to unravel the ecological mysteries at play not only within its small confines, but on distant shores as well.

\section{Acknowledgments}

This work was facilitated by the staff at several herbaria: principally the San Diego Natural History Museum (SD) and the University of Arizona (ARIZ), as well as Arizona State University (ASU), the California Academy of Sciences (CAS), and the U.S. National Herbarium (US). We are extremely grateful to Ray Turner for making available Rod Hastings's photos and field notes from his 1971 trip to Isla Rasa and to Thor Morales for assisting in matching these historic photos. Collections have been made under Mexican federal collecting permit under NOM-126-SEMARNAT-2000.

Velarde received support from the joint fund Fondo Mexicano para la Conservación de la Naturaleza/Lindblad Expeditions-National Geographic/Packard Foundation, as well as from the San Diego Natural History Museum, CONACYT, CONANP, two private donors, Sue Adams and Ruth Applegarth, and an anonymous donor through the San Diego Natural History Museum. The Mexican Navy provided marine transportation. As part of his graduate research at University of California, Riverside, Wilder received funding from the National Science Foundation Graduate Research Fellowship Program and the University of California Institute for Mexico and the United States (UC MEXUS). Felger received support from the Wallace Research Foundation, the David and Lucile Packard Foundation, and the World Wildlife Fund in collaboration with the Área de Protección de Flora 
y Fauna (APFF) "Islas del Golfo de California" in Sonora, the Comisión Nacional de Áreas Naturales Protegidas (CONANP), and Secretaría de Medio Ambiente y Recursos Naturales (SEMARNAT).

\section{Literature Cited}

Anderson D.W., Henny C.J., Godinez-Reyes C., Gress F., Palacios E.L., Santos del Prado K. and Bredy J. 2007. Size of the California Brown Pelican Metapopulation during a Non-El Niño Year. Open-File Report 2007-1299. Geological Survey, Reston. <http://pubs.usgs.gov/of/2007/1299/pdf/ofr20071299.pdf> (accessed May 29, 2013).

Bancroft G. 1927. Notes on the Breeding Coastal and Insular Birds of Central Lower California. The Condor 29:188-195.

Beier E. and Ripa P. 1999. Seasonal Gyres in the Northern Gulf of California. Journal of Physical Oceanography 29:305-311.

Bent A.C. 1919. Life histories of North American diving birds, order Pygopodes. Bulletin of the U.S. National Museum 107. Government Print Office. Washington D.C.

Bowen T. 2000. Unknown Island: Seri Indians, Europeans, and San Esteban Island in the Gulf of California. University of New Mexico Press, Albuquerque.

Bowen T. 2013. The type locality of Craveri's Murrelet (Synthliboramphus craveri). Marine Ornithology 41:49-54.

Carreño A.L. and Helenes J. 2002. Geology and ages of the islands. In: Case T.J., Cody M.L. and Ezcurra E. Eds. A New Island Biogeography of the Sea of Cortés, pp. 14-40, Oxford University Press, New York.

Caso M., González-Abraham C. and Ezcurra E. 2007. Divergent ecological effects of oceanographic anomalies on terrestrial ecosystems of the Mexican pacific coast. Proceedings of the National Academy of Sciences of de United States of America 104:10530-10535.

Case T.J. and Cody M.L., 1983. Island Biogeography of the Sea of Cortéz. University of California Press, Berkeley.

Case T.J., Cody M.L. and Ezcurra E., 2002. A New Island Biogeography of the Sea of Cortés. Oxford University Press, New York.

Cody M.L. and Velarde E. 2002. Land Birds. In: Case T.J., Cody M.L. and Ezcurra E. Eds. A New Island Biogeography of the Sea of Cortés, pp. 271-312, Oxford University Press, New York.

DOF. Diario Oficial de la Federación. 1964. Decreto del 30 de mayo. Declara la Zona de Reserva Natural y Refugio de Aves de Isla Rasa. México, D.F.

DOF. Diario Oficial de la Federación. 2000. Decreto del 7 de junio. Declara el Área de Protección de Flora y Fauna "Islas del Golfo de California". México, D.F.

DOF. Diario Oficial de la Federación. 2005. Decreto del 25 de abril. Declara el Parque Nacional exclusivamente la zona marina que circunda al complejo insular conocido como Archipiélago de San Lorenzo, ubicada en el Golfo de California, frente a las costas del Municipio de Ensenada, Estado de Baja California, con una superficie total de 58,442-80-45,40 hectáreas. México, D.F.

DOF. Diario Oficial de la Federación. 2007. Decreto del 5 de junio. Declara la Reserva de la Biosfera la zona marina conocida como Bahía de los Ángeles, Canales de Ballenas y Salsipuedes, comprendiendo la zona federal marítimo terrestre correspon- diente a la porción de la costa oriental de la península de Baja California, ubicada frente al Municipio de Ensenada, en el estado de Baja California. México, D.F.

NOM-059-SEMARNAT-2010. Protección ambiental-Especies nativas de México de flora y fauna silvestre-Categorías de riesgo y especificaciones para su inclusión, exclusión o cambio-Lista de especies en riesgo.

Douglas R., Gonzalez-Yajimovich O., Ledesma-Vazquez J. and Staines-Urias F. 2007. Climate forcing, primary production and the distribution of Holocene biogenic sediments in the Gulf of California. Quaternary Science Reviews 26:115-129.

Ezcurra E., Bourillón L., Cantú A., Martínez M.E. and Robles A. 2002. Ecological conservation. In: Case T.J., Cody M.L. and Ezcurra, E. Eds. A New Island Biogeography of the Sea of Cortés, pp. 417-444, Oxford University Press, New York.

Felger R.S. 2000. Flora of the Gran Desierto and Río Colorado of Northwestern Mexico. The University of Arizona Press, Tucson.

Felger R.S. and Lowe C.H. 1976. The island and coastal vegetation and flora of the Gulf of California, Mexico. Natural History Museum of Los Angeles County, Contributions in Science 285:1-59.

Felger R.S. and Wilder B.T. in collaboration with Romero-Morales H. 2012. Plant Life of a Desert Archipelago: Flora of the Sonoran Islands in the Gulf of California. The University of Arizona Press, Tucson.

Felger R.S., Johnson M.B. and Wilson M.F. 2001. The Trees of Sonora, Mexico. Oxford University Press, New York.

Felger R.S., Austin D.F., Van Devender T.R., Sánchez-Escalante J. and Costea M. 2012. Convolvulaceae of Sonora, Mexico. I. Convolvulus, Cressa, Dichondra, Evolvulus, Ipomoea, Jacquemontia, Merremia, and Operculina. Botanical Research Institute of Texas 6:459-527.

Gallo-Reynoso J.P., Felger R.S. and Wilder B.T. 2012. Near colonization of a desert Island by a tropical bird: Military Macaw (Ara militaris) at Isla San Pedro Nolasco, Sonora, Mexico. The Southwestern Naturalist 57:459-462.

García A.E. 1964. Modificaciones al Sistema de Clasificación Climática de Köppen para adaptarlo a las condiciones de la República Mexicana. Instituto de Geografía, Universidad Nacional Autónoma de México, México, D.F.

Gentry H.S. 1949. Land Plants Collected by the Valero III, Allan Hancock Pacific Expeditions 1937-1941. Allan Hancock Pacific Expeditions 13. University of Southern California Press. Los Angeles.

Holmgren M., Scheffer M., Ezcurra E., Gutiérrez J.R. and Mohren G.M.J. 2001. El Niño effects on the dynamics of terrestrial ecosystems. Trends in Ecology and Evolution 16:89-94.

Johnston I.M. 1924. Expedition of the California Academy of Sciences to the Gulf of California in 1921: the botany (vascular plants). Proceedings of the California Academy of Sciences, series 4 12:951-1218.

Lavín M.F. and Marinone S.G. 2003. An overview of the physical oceanography of the Gulf of California. In: Velasco Fuentes O.U., Sheinbaum J. and Ochoa J. Eds. Nonlinear Processes in Geophysical Fluid Dynamics, pp. 173-204, Kluwer Academic Publishers, Dordrecht.

López-Medellín X., Ezcurra E., González-Abraham C., Hak J., Santiago L.S. and Sickman J.O. 2011. Oceanographic anomalies and sea-level rise drive mangroves inland in the Pacific coast of Mexico. Journal of Vegetation Science 22:143-151. 
Maya J.A. 1968. The Natural History of the fish-eating bat, $P i$ zonyx vivesi. Ph.D dissertation, University of Arizona, Tucson, $106 \mathrm{pp}$.

Moran R. 1936-1993. The Field Notes of Reid Moran, The Flora of Baja California. San Diego Natural History Museum. Botany Department.<http://bajaflora.org/MoranNotesSearch.aspx> (accessed 29 May, 2013)

Moran R. 1983. Plants on some smaller islands. In: Case T.J. and Cody M.L. Eds. Island Biogeography in the Sea of Cortéz, pp. 404-406, University of California Press, Berkeley.

Moran R. and Rebman J.P. 2002. Plants on some small Gulf islands. In: Case T.J., Cody M.L. and Ezcurra E. Eds. A New Island Biogeography of the Sea of Cortés, pp. 527-534, Oxford University Press, New York.

Murphy R.W. and Aguirre-Léon G. 2002. Distributional checklist of nonavian reptiles and amphibians on the islands in the Sea of Cortés. In: Case T.J., Cody M.L. and Ezcurra E. Eds. A New Island Biogeography of the Sea of Cortés, pp. 580-585, Oxford University Press, New York.

Murphy R.W., Sanchez-Piñero F., Polis G.A. and Aalbu R.L. 2002. New measurements of area and distance for islands in the Sea of Cortés. In: Case T.J., Cody M.L. and Ezcurra E. Eds. A New Island Biogeography of the Sea of Cortés, pp. 447-464, Oxford University Press, New York.

Polis G.A., Hurd S.D., Jackson C.T. and Sánchez Piñero F. 1997. El Niño effects on the dynamics and control of anisland ecosystem in the Gulf of California. Ecology 78:1884-1897.

Rebman J.P. 1995. Biosystematics of Opuntia subgenus Cylindropuntia (Cactaceae): The Chollas of Lower California, Mexico. Ph.D dissertation, Arizona State University, Tempe, 374 pp.

Rose M.D. and Polis G.A. 2000. On the insularity of islands. Ecography 23:693-701.

Rzedowski J. 1991. El endemismo en la flora fanerogámica Mexicana: una apreciación analítica preliminar. Acta Botanica Mexicana 15:47-64.

Samaniego-Herrera A., Aguirre-Muñoz A., Félix-Lizárraga M., Valdez-Villavicencio J., González-Gómez R., Rodríguez-Malagón M., Peralta-García A., Torres-García F., Méndez F., Silva N., Soqui E., Howald G. and Tershy B.R. 2008. Restauración ambiental de las Islas Farallón de San Ignacio y San Pedro Mártir, Golfo de California, México: erradicación de rata negra. In: Flores C.L.M. Ed. Estudios de las Islas del Golfo de California, pp. 167-176, Once Rios Editores, Culiacán.

Stapp P., Polis G.A. and Piñero F.S. 1999. Stable isotopes reveal strong marine and El Niño effects on island food webs. Nature 401:467-469.

Tershy B.R., Breese D., Angeles P.A., Cervantes A.M., Mandujano H.M., Hernández N.E. and Córdoba A.A. 1992. Natural history and management of Isla San Pedro Mártir. Report to Conservation International. Guaymas.

Turner R.M., Bowers J.E. and Burgess T.L. 1995. Sonoran Desert Plants: An Ecological Atlas. The University of Arizona Press, Tucson.

Turner R.M., Webb R.H., Bowers J.E. and Hastings J.R. 2003. The
Changing Mile Revisited: An Ecological Study of Vegetation Change with Time in the Lower Mile of an Arid and Semiarid Region. The University of Arizona Press, Tucson.

Vasey G and Rose J.N. 1890. List of plants collected by Dr. Edward Palmer in Lower California and western Mexico in 1890. Contributions from the United States National Herbarium 1:63-90.

Velarde-González M.E. 1989. Conducta y ecología de la reproducción de la gaviota parda (Larus heermanni) en Isla Rasa, Baja California. Tesis de Doctorado en Ciencias (Biología). Facultad de Ciencias, Universidad Nacional Autónoma de México, Mexico, D.F. 129 pp.

Velarde E. and Anderson D.W. 1994. Conservation and management of seabird islands in the Gulf of California: setbacks and successes. In: Nettleship D.N., Burger J. and Gochfeld M. Eds. Seabirds on Islands: Threats, Case Studies and Action Plans, pp. 229-243, ICBP Technical Publication, Cambridge.

Velarde E. and Ezcurra E. 2002. Breeding dynamics of the Heermann's Gull. In: Case T.J., Cody M.L. and Ezcurra E. Eds. A New Island Biogeography of the Sea of Cortés, pp. 313-325, Oxford University Press, New York.

Velarde E., Hollingsworth B. and Rebman J. 2008. Sauromalus hispidus. Herpetological Review 39:368.

Velarde E., Ezcurra E., Cisneros-Mata M.A. and Lavín M.F. 2004. Seabird ecology, El Niño anomalies, and prediction of sardine fisheries in the Gulf of California. Ecological Applications 14:607-615.

Velarde E., Navarro C.J., Ruiz E.A. and Aguilar A. 2011. The status of Craveri's Murrelet Synthliboramphus craveri and reoccupation of a former nesting area. Marine Ornithology 39:269-273.

Velarde E., Cartron J.L.E., Drummond H., Anderson D.W., Rebón Gallardo F., Palacios E. and Rodríguez C. 2005. Nesting seabirds of the Gulf of California's Offshore islands: diversity, ecology and conservation. In: Cartron J.L.E., Ceballos G. and Felger R.S. Eds. Biodiversity, Ecosystems, and Conservation in Northern Mexico, pp. 452-470, Oxford University Press, New York.

Vidal N. 1967. Aportación al conocimiento de Isla Rasa, Baja California. Bachelor's dissertation. Universidad Nacional Autónoma de México. México, D.F. 48 pp.

Vieyra L., Velarde E. and Ezcurra E. 2009. Effects of parental age and food availability on the reproductive success of Heermann's Gulls in the Gulf of California. Ecology 90:1084-1094.

Villa R.B. 1976. Isla Rasa, Baja California, enigma y paradigma. Supervivencia 2:17-29.

Walker L.W. 1951. Sea birds of Isla Raza. National Geographic 99:239-248.

Wilder B.T. and Felger R.S. 2010. Dwarf Giants, Guano, and Isolation: Vegetation and floristic diversity of San Pedro Mártir Island, Gulf of California, Mexico. Proceedings of the San Diego Society of Natural History 42:1-24.

Wilder B.T., Felger R.S. and Romero-Morales H. 2008. Succulent plant diversity of the Sonoran Islands, Gulf of California, Mexico. Haseltonia 14:127-160.

Received: April 4th, 2013

Accepted: June 16th, 2013 